\title{
Alcohol and narcotics use in inflammatory bowel disease
}

\author{
George Mantzouranis ${ }^{a}$, Eleftheria Fafliora ${ }^{a}$, Maria Saridi ${ }^{b}$, Athina Tatsioni ${ }^{a}$, George Glanztounis ${ }^{a}$, \\ Eleni Albanic, Konstantinos H. Katsanos ${ }^{\text {, }}$, Dimitrios K. Christodouloua
}

University of Ioannina, Medical School; University of Peloponnese, Corinth; TEI of Western Greece, Greece

\section{Abstract}

\begin{abstract}
The aim of this study was to evaluate alcohol consumption and narcotics use among patients with inflammatory bowel diseases (IBD). A comprehensive literature search was conducted in Medline using relevant keywords. The references of the retrieved articles were also searched to identify additional articles. Only English-language studies that provided evidence on alcohol consumption and/or narcotics use among non-hospitalized IBD patients were included in the present review. Twelve studies were included that examined the use of alcohol among IBD patients. The prevalence of alcohol consumption among IBD patients appeared to be similar to that of the general population. The majority of the studies reported worsening of IBD symptoms among patients who consumed alcoholic beverages. Four studies were identified that evaluated narcotics use as analgesia among IBD patients. Narcotics use was prevalent among IBD patients and correlated with a longer disease duration and comorbid mental illnesses. The available evidence suggests that alcohol consumption may have a deleterious effect on IBD symptoms. Furthermore, a considerable proportion of IBD patients are reported to use a narcotic as analgesia and this was correlated with their mental health status. Further studies are needed to address these important facets of IBD.
\end{abstract}

Keywords Inflammatory bowel disease, Crohn's disease, ulcerative colitis, alcohol, narcotics

Ann Gastroenterol 2018; 31 (6): 1-10

\section{Introduction}

Inflammatory bowel diseases (IBD) are a group of chronic relapsing disorders of the gastrointestinal tract whose major types are ulcerative colitis (UC) and Crohn's disease (CD). The incidence of these disorders in Europe has increased during the last 50 years [1]: for UC from 6.0 per 100,000 person-years to 9.8 per 100,000 person-years and for CD from 1.0 per 100,000 person-years to 6.3 per 100,000 person-years [1].

Although IBD seems to represent a result of a dysregulated host-microbe interaction in genetically susceptible individuals, its etiology has not been sufficiently established [2]. Several

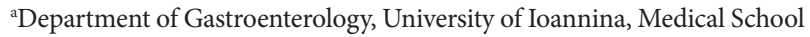
(George Mantzouranis, Eleftheria Fafliora, Athina Tatsioni, George Glantzounis, Konstantinos H. Katsanos, Dimitrios K. Christodoulou); ${ }^{b}$ Department of Social Sciences, University of Peloponnese, Corinth, Academic Tutor at Hellenic Open University (Maria Saridi); 'Department of Nursing, TEI of Western Greece (Eleni Albani), Greece

\section{Conflict of Interest: None}

Correspondence to: Maria Saridi, PhD, Research Fellow, Faculty of Social Sciences, University of Peloponnese, Corinth, Greece, Academic Tutor at Hellenic Open University, Greece, Sina 33, 20131 Corinth, Greece, e-mail: sarmar32@windowslive.com

Received 20 March 2018; accepted 3 July 2018; published online 1 August 2018

DOI: https://doi.org/10.20524/aog.2018.0302 risk factors have been studied, including genetic factors, psychological factors or other environmental factors such as smoking [2,3]. Among these, diet is implicated in both the development and the course of IBD. Specifically, a western pattern diet comprising high amounts of fat and sugar and low amounts of fiber has been reported to contribute to the development of IBD [2-4]. In addition, several studies have examined the impact of alcohol consumption on IBD $[5,6]$.

Alcohol consumption is well known to be both proinflammatory and directly harmful to gut barrier function, as it breaks down the normal physical and immunological barrier provided by intestinal epithelial cells and gut-associated lymphoid tissue, respectively [7]. Clinical studies have indicated that alcohol consumption may provoke symptoms and/or relapse in an inactive disease [8]. The potential influence of alcohol use on IBD pathogenesis seems to be greater in adults [9].

Patients who suffer from $\mathrm{CD}$ are prone not only to the complications of a relapsing, unpredictable disease, but also to feelings of stigmatization, depression and increased risk of suicidal ideation, suicide, or drug and alcohol abuse [10]. Substance abuse and concurrent psychiatric disorders could be associated with several factors in chronic prescription narcotic users [11]. Furthermore, one of the main symptoms of IBD is abdominal pain; therefore, narcotics are often prescribed for pain relief for short periods.

Pain related to disease activity, complications, or surgeries is often treated with opioid analgesics. Because of concerns about risks or side effects of medications, many patients have 
an interest in alternative therapies, alone or as a supplement to standard treatment protocols [12]. A significant positive relationship has been reported between the use of narcotic analgesics and the development of serious infections in CD patients [13]. However, because of the chronic course of the disease, the number of flares, or comorbidities such as anxiety or depression, many patients end up using these drugs for longer periods than originally planned $[14,15]$. Narcotic use has not been shown to be effective in the management of CD, but patients with $\mathrm{CD}$ have been found to have fairly high rates of chronic prescription narcotic use [16].

The aim of this review was to gather the available evidence on the role of alcohol in the development and course of IBD as well as the prevalence of narcotics use among non-hospitalized IBD patients.

\section{Materials and methods}

We conducted a comprehensive literature review of the Medline database from inception through to March 2016. We utilized the Boolean search operators "AND" and "OR", the PubMed Advanced Search Builder and the relevant search filters. The following keywords were used in our search: inflammatory bowel disease, Crohn's disease, ulcerative colitis, alcohol, wine, beer, drug abuse, narcotics, opioid. The references of the retrieved articles were searched manually to identify additional studies.

We included only English-language studies that investigated the use of alcohol or narcotics among IBD patients. In the case of narcotics, we included only studies that examined their use as analgesics for IBD-related pain. We excluded studies that did not provide any relevant information, those that included only hospitalized patients, as well as studies whose full text we were not able to retrieve through our library.

The details of the research items, with reference to Participants, Interventions, Comparisons, Outcomes, and Study design (PICOS/PRISMA) [17] are presented in Fig. 1 and in detail in Fig. 2. Twelve studies were identified that examined the use of alcohol among IBD patients $[5,6,18-27]$ and 4 that examined narcotics use $[14,15,28,29]$. Of the studies examining alcohol use, 3 provided data on the prevalence of alcohol use [18-20], 1 investigated the association between alcohol use and the development of IBD [21], and 8 examined the impact of alcohol consumption on IBD symptoms [5,6,22-26].

According to some studies, moderate alcohol consumption is defined as having up to 1 drink per day for women and up to 2 drinks per day for men. This definition refers to the amount consumed on any single day and is not intended as an average over several days [30]. Studies included in our research present heterogeneity, but this definition is in any case difficult to process.

\section{Results}

\section{Alcohol use and the development of IBD}

Two studies were conducted in Copenhagen in order to determine whether patients with UC or CD differed significantly in terms of various parameters, including alcohol consumption, compared to controls. In the first study, the researchers interviewed 122 UC patients attending an outpatient gastroenterology clinic and 83 sex- and age-matched controls admitted to the same hospital for various other reasons. They collected data on patients' social and professional status, as well as daily alcohol intake, and they reported that the daily alcohol consumption was equal in both groups [18]. Likewise, another study enrolled $106 \mathrm{CD}$ patients and 75 controls and performed personal interviews about the patients' and controls' family, social and professional conditions, as well as alcohol intake. The majority of CD patients reported that they did not drink alcohol (74\%), 24\% of them drank up to 5 glasses of alcohol per day, whereas only $2 \%$ drank more than 5 glasses per day. Similarly, $79 \%$ of the controls reported that they did not drink, while only a small percentage (4\%) drank more than 5 glasses per day. The results showed that alcohol intake did not differ between CD patients and controls [19].

The prevalence of alcohol use was studied among 403 patients aged 9-18 years with chronic conditions through the completion of a self-administered questionnaire. Almost one third of all participants (30.8\%) reported past-year alcohol use, whereas older age was positively associated with alcohol

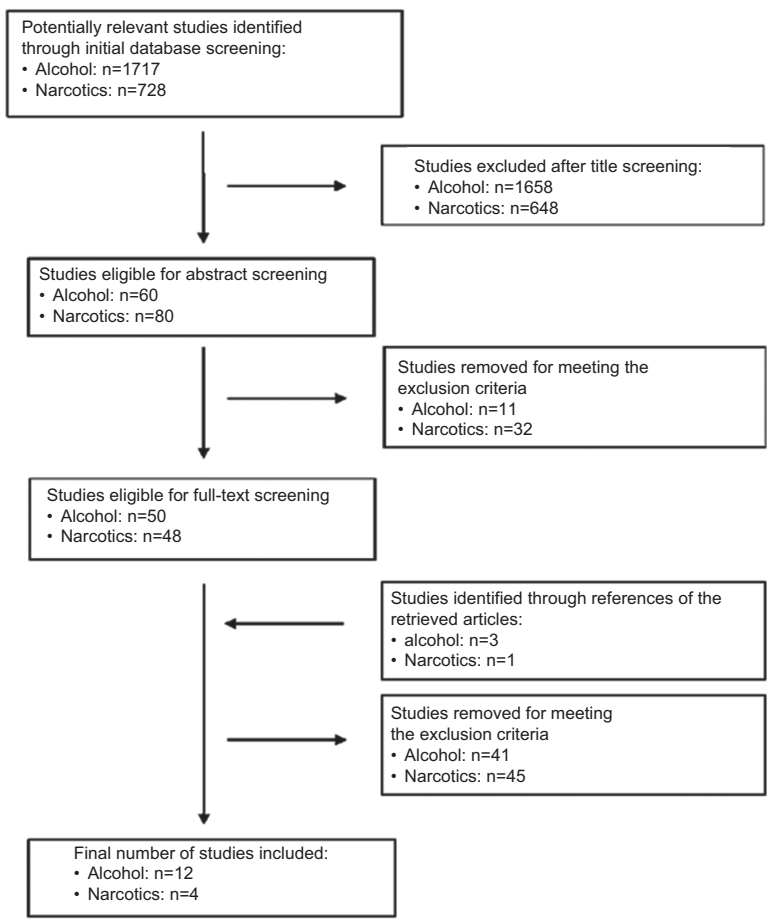

Figure 1 Flowchart of the search strategy 


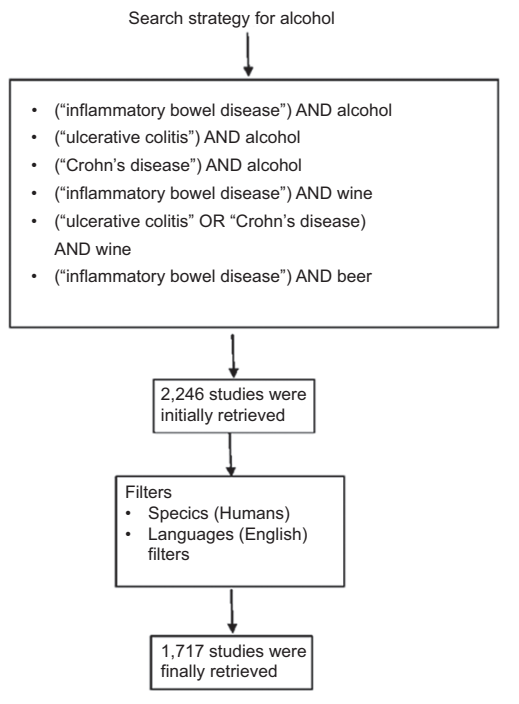

Figure 2 Search strategy in details

use. It should be noted that, among all participants, $53.1 \%$ were aware of the fact that alcohol can interfere with medications and $37.2 \%$ that alcohol can interfere with laboratory tests. The results showed that a total of 100 patients had IBD and 39.5\% reported past-year alcohol use, and approximately half (46.9\%) reported binge drinking [20].

Possible risk factors for the development of UC were investigated in a Chinese population. In this study, 177 UC patients and 177 controls, either neighbors or colleagues of the patients, completed a structured questionnaire regarding various risk factors. Alcohol drinking was classified as frequent when the individuals drank on 3 or more days per week, light when they drank on fewer than 3 days per week, and nondrinking when they never or rarely drank. A protective effect against the development of UC was reported for light drinking compared with never drinking (odds ratio [OR] 0.52, 95\% confidence interval $[\mathrm{CI}]$ 0.32-0.85, $\mathrm{P}=0.009$ ), however this protective effect was not confirmed by the multivariate analysis of risk factors [21].

The studies that examined the impact of alcohol consumption on IBD symptoms are presented in Table 1. The association of dietary factors and the likelihood of relapse among UC patients was studied among 183 participants who were asked to complete a food frequency questionnaire and the clinical colitis activity index to determine relapse or remission of the disease. High alcohol intake was associated with a higher frequency of reported relapses (OR 2.71; 95\%CI 1.106.67). The median daily consumption of alcoholic beverages reported by the group of patients with frequent relapses was $238 \mathrm{~g}$, whereas in the non-relapse group of patients the daily consumption was $150 \mathrm{~g}$. The authors also found an association between relapses and a high intake of sulfite (OR 2.61; 95\%CI 1.08-6.30), an additive commonly found in processed foods as well as alcoholic beverages [22].

The impact of diet on disease activity among 81 UC patients was examined by a study in which all participants completed

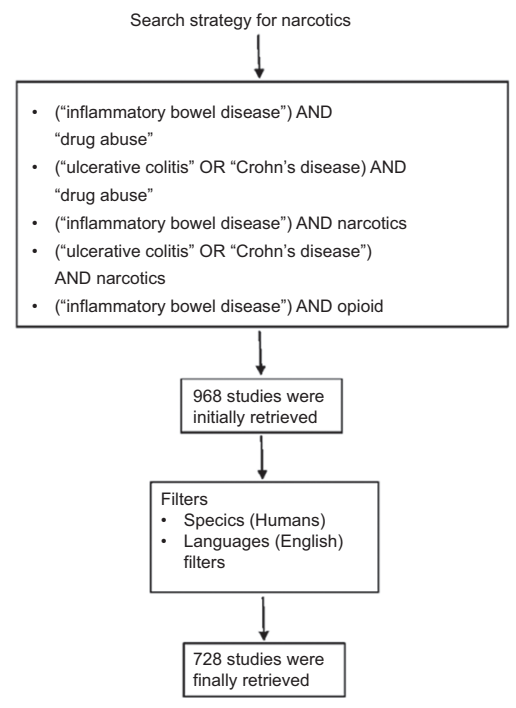

a 7-day diet diary, after which they underwent a clinical assessment of disease activity, including a sigmoidoscopic examination, and were assigned clinical scores [23]. In order to estimate the impact of diet on clinical scores the investigators developed a Food Sigmoidoscopy Score (FSS). A higher FSS was associated with high consumption of each particular food examined in the study and high levels of disease activity. The consumption of red wine and beer was positively correlated with the sigmoidoscopy scores $\left(r^{2}=0.07, \mathrm{P}<0.02\right)$. Red wine, white wine, bitter and lager were associated with higher FSS (Mann-Whitney, $\mathrm{P}<0.001$ ). All these alcoholic beverages had in common the fact that they contain sulfite. On the other hand, spirits, which do not contain sulfite, were not associated with UC disease activity. Therefore, the authors suggested that sulfite, rather than alcohol, was affecting UC disease activity [5].

The CD patients' perspectives on the factors that may be associated with their symptoms was examined in a study in which $1220 \mathrm{CD}$ patients participated. The majority of CD patients who consumed alcohol preferred beer (43\%), wine (36\%), liquors (44.8\%), or mixed drinks (41\%). Interestingly, 4 of 10 reported that alcohol worsened their symptoms, whereas the same proportion reported that alcohol consumption did not have an impact on their symptoms. When the different alcoholic beverages were compared, their association with the worsening of symptoms showed no significant variation [23]. A similar study tried to evaluate the impact of 5 different alcoholic beverages on gastrointestinal symptoms and disease activity when given to fasting CD patients in remission [24]. For this purpose they recruited $20 \mathrm{CD}$ patients in remission (Crohn's Disease Activity Index score <150) and 20 healthy controls, all of whom underwent 6 -h fast and were not allowed to consume alcohol for $48 \mathrm{~h}$ prior to the investigation. The participants were randomly given either $36 \mathrm{~g}$ (men) or $24 \mathrm{~g}$ (women) of 5 different alcoholic drinks (red wine, white wine, Smirnoff Ice, Elephant Beer, or pure ethanol). They 
Table 1 Characteristics of the studies evaluating the impact of alcohol consumption on symptoms among patients with IBD $(n=8)$

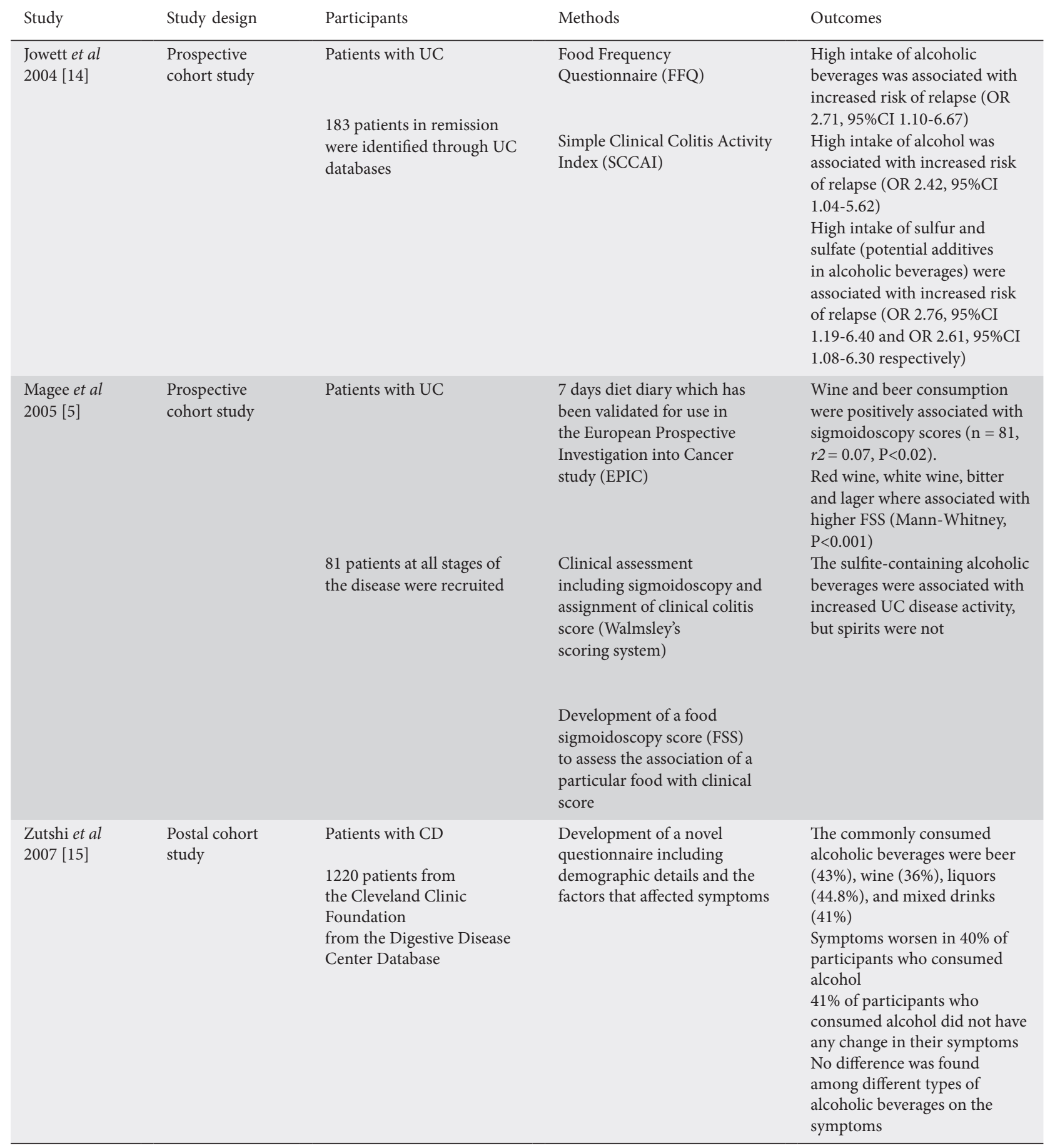

(Contd...) 
Table 1 (Continued)

\begin{tabular}{|c|c|c|c|c|}
\hline Study & Study design & Participants & Methods & Outcomes \\
\hline $\begin{array}{l}\text { Hey et al } \\
2007[16]\end{array}$ & $\begin{array}{l}\text { Case-control } \\
\text { study }\end{array}$ & $\begin{array}{l}20 \text { patients with } \mathrm{CD} \text { in } \\
\text { remission }\end{array}$ & $\begin{array}{l}\text { According to the Danish } \\
\text { Department of Health the } \\
\text { participants randomly } \\
\text { received } 36 \mathrm{~g} \text { (men) and } 24 \mathrm{~g} \\
\text { (women) of different alcoholic } \\
\text { beverages ( red wine, white } \\
\text { wine, Smirnoff Ice, Elephant } \\
\text { Beer or pure ethanol) } \\
\text { Venous blood samples were } \\
\text { obtained at } 0,30,60,90,120 \\
\text { and } 180 \text { min post-drinking. A } \\
\text { self-reported pain symptom } \\
\text { score for registration of } \\
\text { abdominal pain was used }\end{array}$ & $\begin{array}{l}\text { Compared to pure ethanol, } \\
\text { the absorption of alcohol was } \\
\text { reduced, especially in Smirnoff } \\
\text { Ice (by } 35 \% \text { ), in red wine (by } \\
19 \% \text { ) and in beer (by } 13 \% \text { ) } \\
\text { CD patients that received } \\
\text { Smirnoff Ice or Elephant beer } \\
\text { were more likely to develop } \\
\text { abdominal pain compared } \\
\text { to those who consumed pure } \\
\text { ethanol (P<0.05) } \\
\text { No increase in disease activity } \\
\text { was reported } \\
\text { No changes in the } \\
\text { inflammatory markers were } \\
\text { reported }\end{array}$ \\
\hline $\begin{array}{l}\text { Swanson et al } \\
\text { (a) } 2010 \text { [6] }\end{array}$ & $\begin{array}{l}\text { Cross-sectional } \\
\text { study }\end{array}$ & $\begin{array}{l}52 \text { patients with CD in } \\
\text { remission, } 38 \text { patients with } \\
\text { UC in remission and } 39 \\
\text { patients with IBS } \\
\text { Patients were recruited } \\
\text { from a metropolitan } \\
\text { university practice and a } \\
\text { private gastroenterology } \\
\text { clinic }\end{array}$ & $\begin{array}{l}\text { Crohn's disease activity index } \\
\text { (CDAI) } \\
\text { Ulcerative colitis activity index } \\
\text { (UCAI) } \\
\text { Validated questionnaire } \\
\text { regarding alcohol } \\
\text { consumption (National } \\
\text { Institute of Alcohol Abuse } \\
\text { and Alcoholism) } \\
\text { Development of a novel } \\
\text { questionnaire regarding the } \\
\text { effect of alcohol consumption } \\
\text { on symptoms } \\
\text { General Gastrointestinal } \\
\text { Rating Severity Form }\end{array}$ & $\begin{array}{l}54 \% \text { of CD patients, } 61 \% \text { of } \\
\text { UC patients, and } 49 \% \text { of IBS } \\
\text { patients were current drinkers } \\
\text { Current drinkers with inactive } \\
\text { IBD reported worsening } \\
\text { of symptoms with alcohol } \\
\text { compared to the current } \\
\text { drinkers with IBS ( } \mathrm{P}=0.01 \text { ) } \\
\text { No difference in overall } \\
\text { severity of symptoms when } \\
\text { compared with quantity of } \\
\text { alcohol consumed } \\
\text { IBS patients reported more } \\
\text { severe symptoms than IBD } \\
\text { patients (P=0.02) } \\
\text { No correlation was identified } \\
\text { between the type of alcoholic } \\
\text { beverage consumed and } \\
\text { symptoms in IBD or IBS } \\
\text { patients }\end{array}$ \\
\hline $\begin{array}{l}\text { Triggs et al } \\
2010[17]\end{array}$ & Cohort study & $\begin{array}{l}\text { Canterbury inflammatory } \\
\text { bowel disease project } \\
\text { and North Island-based } \\
\text { study "Genes and diet } \\
\text { in inflammatory bowel } \\
\text { disease" databases }\end{array}$ & $\begin{array}{l}\text { Development of a food } \\
\text { tolerance questionnaire }\end{array}$ & $\begin{array}{l}\text { Champagne, beer, red and } \\
\text { white wine increased the } \\
\text { adverse effects in more than } \\
45 \% \text { of CD patients } \\
\text { Champagne, beer, red and } \\
\text { white wine were beneficial for } \\
\text { less than } 5 \% \text { of CD patients }\end{array}$ \\
\hline
\end{tabular}

(Contd...) 
Table 1 (Continued)

\begin{tabular}{|c|c|c|c|c|}
\hline Study & Study design & Participants & Methods & Outcomes \\
\hline $\begin{array}{l}\text { Swanson et al } \\
\text { (b) } 2011 \text { [18] }\end{array}$ & $\begin{array}{l}\text { Prospective } \\
\text { cohort study }\end{array}$ & $\begin{array}{l}6 \text { patients with } \mathrm{CD} \text { in } \\
\text { remission, } 8 \text { patients with } \\
\mathrm{UC} \text { in remission and } 7 \\
\text { healthy controls }\end{array}$ & $\begin{array}{l}\text { Baseline laboratory tests after } \\
1 \text { week of alcohol abstinence } \\
\text { All participants consumed 1-3 } \\
\text { glasses of the same brand of } \\
\text { red wine per day for } 7 \text { days } \\
\text { Repeat laboratory tests after } \\
\text { alcohol consumption }\end{array}$ & $\begin{array}{l}\text { No patients flared or } \\
\text { experienced a worsening of } \\
\text { their symptoms or diarrhea } \\
\text { during the trial } \\
\text { No change in either clinical } \\
\text { activity index after wine } \\
\text { consumption } \\
\text { Stool calprotectin was reduced } \\
\text { after the consumption of red } \\
\text { wine in IBD subjects compared } \\
\text { to baseline ( } \mathrm{P}=0.001 \text { ) } \\
\text { Urinary lactulose/mannitol } \\
\text { ratio excretion was increased in } \\
\mathrm{CD} \text { subjects }(\mathrm{P}=0.028) \text {, but not } \\
\text { in patients with } \mathrm{UC} \\
\text { Urinary sucralose excretion } \\
\text { was significantly increased in } \\
\mathrm{UC}(\mathrm{P}=0.012) \text {, but not in CD } \\
\text { patients }\end{array}$ \\
\hline $\begin{array}{l}\text { Cohen et al } \\
2013 \text { [19] }\end{array}$ & Cohort study & $\begin{array}{l}1121 \text { patients with CD, } 597 \\
\text { patients with UC, } 405 \mathrm{CD} \\
\text { patients with ostomy and } \\
206 \text { UC patients with pouch } \\
\\
\text { Patients were recruited } \\
\text { from the Crohn's and } \\
\text { Colitis Foundation of } \\
\text { America database }\end{array}$ & $\begin{array}{l}\text { Semi-quantitative food } \\
\text { frequency questionnaire } \\
\text { (National Cancer Institute) } \\
\text { Self-reported disease activity }\end{array}$ & $\begin{array}{l}\text { Alcohol worsened symptoms } \\
\text { among CD patients, UC } \\
\text { patients and UC patients with } \\
\text { pouch }(\mathrm{P}<0.01)\end{array}$ \\
\hline
\end{tabular}

UC, ulcerative colitis; $C D$, Crohn's disease; IBS, irritable bowel syndrome; IBD, inflammatory bowel disease

then underwent consecutive blood sampling up to $3 \mathrm{~h}$ after alcohol consumption, to assess serum ethanol and plasma glucose concentrations, and they also reported abdominal pain symptom scores at each time. No difference was observed in ethanol concentration between patients and controls, whereas plasma glucose levels were significantly higher $(\mathrm{P}<0.05)$ among CD patients who consumed either Smirnoff Ice or Elephant Beer. Interestingly, the $\mathrm{CD}$ patients who consumed the aforementioned high-sugar drinks reported more pronounced abdominal pain compared to those who consumed pure ethanol $(\mathrm{P}<0.05)$; however, no increase in disease activity index was reported [24].

The role of the quantity of alcohol consumption in IBD symptoms and the self-reported effects were investigated in a study of 129 UC, CD, and irritable bowel syndrome (IBS) patients. All IBD patients included in the study had biopsyproven CD or UC. IBS patients had to meet the Rome II criteria for IBS, and had a normal colonoscopy. The authors followed the National Institute of Alcohol Abuse and Alcoholism (NIAAA) to classify the patients into abstainers $(<12$ drinks per year), current drinkers ( $>12$ drinks per year), light drinkers ( $\leq 3$ drinks per week), moderate drinkers ( $>3$ to $\leq 14$ drinks per week), heavy drinkers ( $>14$ drinks per week), and binge drinkers ( $>5$ drinks on one occasion). More than half of the $\mathrm{CD}$ and UC patients were current drinkers. Among these, 21\% of CD patients and $26 \%$ of UC patients were light drinkers, whereas $33 \%$ and $24 \%$, respectively, were moderate drinkers. The authors noted that alcohol consumption patterns among IBD patients were similar to those of the general population. The majority of CD and UC patients who were current drinkers reported worsening of their symptoms with alcohol consumption, whereas this did not apply to the IBS patients. IBD patients with upper gastrointestinal symptoms consumed less alcohol than IBD patients without these symptoms. However, no statistical association was reported between the severity of the symptoms and the quantity of alcohol consumed, while the type of alcoholic beverage also did not appear to play a role [6].

A similar study attempted to evaluate the dietary tolerances and intolerances of $446 \mathrm{CD}$ patients. All participants were asked to complete a food tolerance questionnaire, which included 257 food items, by scoring the items on a 5-point scale. Items with the most negative numbers were considered as the least beneficial. More than half of the responders reported that beer, red wine and champagne increased the adverse effects. Four of 5 reported that the consumption of white wine had an adverse effect on their symptoms. Only a small percentage of the participants reported that alcoholic beverages were well tolerated, with red wine having a beneficial effect on almost $5 \%$ of CD patients [25]. Another study aimed to evaluate the effects of moderate alcohol drinking on markers of disease activity in inactive IBD, namely stool calprotectin and intestinal permeability. The researchers recruited 23 IBD patients, 
all social drinkers, in clinical remission and asked them to complete questionnaires regarding alcohol consumption and disease activity. Upon enrollment the participants were asked to refrain from drinking alcohol for a period of 1 week, after which blood, stool and urine samples were collected as baseline assessment from the IBD patients and from 7 healthy controls. The patients were then instructed to drink 1-3 glasses of red wine per day for a period of 1 week, after which they underwent repeat examinations. None of the participants reported worsening of their symptoms and the clinical activity indexes before and after the alcohol consumption did not differ. Stool calprotectin was significantly decreased compared to baseline after 1 week of alcohol consumption in IBD patients $(\mathrm{P}=0.001)$. Markers of intestinal permeability were similar among IBD patients and controls at baseline. Wine consumption significantly affected these markers in IBD patients: namely, urinary lactulose/mannitol excretion was increased in $\mathrm{CD}$ patients $(\mathrm{P}=0.028)$ and urinary sucralose secretion was increased in UC patients $(\mathrm{P}=0.012)$ [26].

Finally, Cohen et al utilized the cohort of an internetbased study and included 6768 patients in their study. All participants completed a survey that included a food frequency questionnaire originally developed by the National Cancer Institute, as well as open-ended questions regarding the patients' perceptions of the impact of food items on their symptoms. Alcohol was found to significantly worsen symptoms among CD patients without ostomy or pouch, UC patients without ostomy and pouch, as well as UC patients with a pouch $(\mathrm{P}<0.01)[27]$.

\section{Narcotics use among IBD patients}

The studies that examined the narcotics use among IBD patients are presented in Table 2. The Diagnostic and Statistical Manual of Mental Disorders was used to establish a psychiatric diagnosis of 1500 participants in a study of IBD patients. Based on this analysis, $30.2 \%$ of these patients were found to meet the criteria for drug dependence. The most common source of drug dependence was iatrogenic and dependence was observed an average of 7.4 years after the diagnosis of IBD. In addition, 38\% of the patients who were drug dependent were also diagnosed with a borderline personality disorder, compared with $7 \%$ of the patients who were not drug dependent [14].

In a similar study, the authors utilized a large IBD database to evaluate the prevalence of chronic narcotic use among 332 IBD patients and they defined chronic narcotic use as either the continuous use of oral codeine (>300 mg/week) for abdominal pain, or frequent intermittent narcotic use (morphine, pethidine, physeptone) over a period of at least 6 months. They reported that $2.7 \%$ of all IBD patients, $5.1 \%$ of CD patients and 1 UC patient were chronic narcotics users. CD patients who used narcotics had been diagnosed with CD for an average of 15 years. It is notable that no evidence of disease flare-ups was found among IBD patients using narcotics over the period of the study. IBD narcotic users were more likely to have been diagnosed at some time with a comorbid psychiatric disorder, or to have had a psychiatric diagnosis prior to the
IBD diagnosis, than IBD patients not using narcotics (OR 22, 95\%CI 3.24-177, $\mathrm{P}=0.002$; and OR 9.6, 95\%CI 1.36-67, $\mathrm{P}=0.045$, respectively) [28].

Another study of narcotics use in IBD patients was carried out in a specialized IBD clinic and the researchers tried to assess the disease activity, the self-reported prevalence of opioid analgesic use among the patients, and its association with the health-related quality of life (HRQoL). They also used the Harvey Bradshaw Index (HBI) and the inflammatory bowel disease questionnaire (IBDQ) to evaluate the disease activity and the HRQoL, respectively. Thirty-eight IBD patients used opioids and there were several differences between opioid users and non-opioid users. Among opioid users the average duration of disease was significantly longer, the number of hospital admissions was greater, the number of surgeries was greater and the use of prednisone was more frequent compared to non-opioid users ( 18.5 vs. 9 years, $\mathrm{P}=0.005$; median 5 vs. $1, \mathrm{P}<0.001$; median 3 vs. $0, \mathrm{P}<0.001$; and $29 \%$ vs. $11.3 \%$, $\mathrm{P}=0.03$, respectively). Furthermore, opioid users had more active disease and impaired HRQoL as compared to nonopioid users (HBI score 9 vs. 3, $\mathrm{P}<0.01$; IBDQ score 109.3 vs. 162.9, $\mathrm{P}<0.001)$. Higher daily opioid use was associated with lower HRQoL $(r=-0.58, \mathrm{P}<0.001)$. IBD patients using more than $50 \mathrm{mg}$ daily of oral morphine had significantly impaired HRQoL as compared to those using less than $50 \mathrm{mg}$ (IBDQ score 99.3 vs. $116.6, \mathrm{P}=0.001$ ) [29].

Finally, Buckley et al, using an administrative claims database, investigated narcotics use among the pediatric IBD population (aged 0-18 years old). A total of 4334 children with IBD and 21720 randomly sampled healthy controls were included in the study. The authors used prescription drug claims to establish narcotics use and defined participants who had 3 or more narcotic drug claims during a 2 -year period as chronic users. They reported that $5.6 \%$ of IBD children were chronic narcotics users and that this population had twice the prevalence odds ratio (POR) of narcotic use as compared with controls (POR 2.59, 95\%CI 2.21-3.04). Furthermore, chronic narcotics use and IBD status were significantly more strongly associated among younger children with IBD (aged 0-9 years old) and children with IBD and a comorbid mental health problem (anxiety, depression, use of relevant medications or any psychological impairment) [15]. Older age, male sex, the presence of any psychological impairment, oral steroid use and a greater number of outpatient visits were among the factors associated with higher chronic narcotics use among children with IBD (POR 3.06, 95\%CI 1.61-5.84; POR 1.02, 95\%CI 0.761.37; POR 2.72, 95\%CI 2.02-3.67; POR 1.00, 95\%CI 0.73-1.35; and POR 1.87, 95\%CI 1.20-2.91, respectively) [18].

\section{Discussion}

Several possible mechanisms have been suggested through which alcohol consumption may impact on IBD symptoms. It has been reported that alcohol consumption could affect the luminal immune system by increasing intestinal permeability and antigen exposure. Furthermore, the high sugar content of 
Table 2 Characteristics of the studies evaluating the narcotics use among patients with inflammatory bowel disease (IBD) ( $\mathrm{n}=4)$

\begin{tabular}{|c|c|c|c|c|}
\hline Study & Study design & Participants & Methods & Outcomes \\
\hline $\begin{array}{l}\text { Kaplan et al } \\
1988 \text { [8] }\end{array}$ & Cohort study & 43 patients with IBD & $\begin{array}{l}\text { Diagnosis based on the } \\
\text { diagnostic and statistical } \\
\text { manual of mental disorders }\end{array}$ & $\begin{array}{l}30.1 \% \text { of the IBD patients were drug } \\
\text { dependent } \\
\text { Iatrogenic drug dependence was the } \\
\text { most common pattern occurring an } \\
\text { average of } 7.4 \text { years after the onset } \\
\text { of IBD } \\
38 \% \text { of the IBD patients who were } \\
\text { drug dependent had a borderline } \\
\text { personality in contrast with } 7 \% \text { in the } \\
\text { non-drug dependent group }\end{array}$ \\
\hline $\begin{array}{l}\text { Edwards et al } \\
2001[20]\end{array}$ & Cohort study & $\begin{array}{l}322 \text { patients with IBD } \\
\text { recruited from the Brisbane } \\
\text { IBD Research Group } \\
\text { database }\end{array}$ & $\begin{array}{l}\text { Chronic narcotic use was } \\
\text { defined as continuous oral } \\
\text { codeine (>300 mg/week) } \\
\text { for abdominal pain (not } \\
\text { diarrhea) or frequent } \\
\text { intermittent narcotic } \\
\text { (morphine, pethidine, } \\
\text { physeptone) use over a } \\
\text { period of } 6 \text { months or more }\end{array}$ & $\begin{array}{l}2.7 \% \text { of all IBD patients, } 5.1 \% \text { of } \\
\text { CD patients and } 1 \text { UC patient were } \\
\text { chronic narcotics users } \\
44 \% \text { of IBD patients using narcotics } \\
\text { had a psychiatric diagnosis predating } \\
\text { IBD diagnosis compared to } 8 \% \text { of } \\
\text { IBD patients not using narcotics (OR } \\
\text { 9.6; } 95 \% \text { CI } 1.36-67, \mathrm{P}=0.045 \text { ) } \\
\text { IBD narcotic users were more likely } \\
\text { to have been ever diagnosed with } \\
\text { a comorbid psychiatric disorder } \\
\text { compared to IBD patients not using } \\
\text { narcotics (OR 22; } 95 \% \text { CI } 3.24-177 \text {, } \\
P=0.002 \text { ) }\end{array}$ \\
\hline $\begin{array}{l}\text { Sanford et al } \\
2014 \text { [21] }\end{array}$ & $\begin{array}{l}\text { Cross- } \\
\text { sectional study }\end{array}$ & $\begin{array}{l}93 \text { patients with CD } \\
\text { recruited from a specialized } \\
\text { Inflammatory Bowel Disease } \\
\text { Clinic }\end{array}$ & $\begin{array}{l}\text { Harvey Bradshaw Index } \\
\text { (HBI) to assess disease } \\
\text { activity } \\
\text { Inflammatory Bowel } \\
\text { Disease Questionnaire } \\
\text { (IBDQ) to assess } \\
\text { healthrelated quality } \\
\text { of life (HRQoL) }\end{array}$ & $\begin{array}{l}38 \text { of the patients used opioids } \\
\text { Median disease duration was longer } \\
\text { in patients using opioids compared } \\
\text { to nonopioid users ( } 18.5 \text { vs. } 9 \text { years, } \\
\mathrm{P}=0.005 \text { ) } \\
\text { Patients using opioids had a greater } \\
\text { number of hospital admissions } \\
\text { (median } 5 \text { vs. } 1, \mathrm{P}<0.001 \text { ) and } \\
\text { surgeries related to their } \mathrm{CD} \text { (median } \\
3 \text { vs. } 0, \mathrm{P}<0.001 \text { ) } \\
\text { Disease activity was higher in } \\
\text { patients using opioids ( } 9.0 \text { vs. } 3.0 \text {, } \\
\mathrm{P}<0.001 \text { ) } \\
\text { IBDQ scores were significantly lower } \\
\text { in participants using opioids ( } 109.3 \\
\text { vs. } 162.9, \mathrm{P}<0.001 \text { ) } \\
\text { Total daily opioid dose was inversely } \\
\text { associated with } \mathrm{HRQ} \text { RoL (Spearman } \\
\text { coefficient }-0.58, \mathrm{P}<0.001 \text { ) }\end{array}$ \\
\hline $\begin{array}{l}\text { Buckley et al } \\
2015 \text { [9] }\end{array}$ & $\begin{array}{l}\text { Cross- } \\
\text { sectional study }\end{array}$ & $\begin{array}{l}4,334 \text { children ( } \leq 18 \text { years } \\
\text { old) with IBD and } 21,720 \\
\text { healthy controls recruited } \\
\text { from the Commercial } \\
\text { Claims and Encounters } \\
\text { Market-Scan database }\end{array}$ & $\begin{array}{l}\text { Chronic narcotic use was } \\
\text { defined as at least } 3 \text { narcotic } \\
\text { drug claims during the } \\
\text { 2-year study period }\end{array}$ & $\begin{array}{l}5.6 \% \text { of children with IBD were } \\
\text { chronic narcotic users } \\
\text { Children with IBD were more likely } \\
\text { to be chronic narcotics users than the } \\
\text { members of the general population } \\
\text { (POR } 2.59 \text {; } 95 \% \text { CI } 2.21-3.04 \text { ) } \\
\text { The association between IBD } \\
\text { status and chronic narcotic use was } \\
\text { stronger among children with IBD } \\
\text { who also had mental health problem } \\
\text { (POR } 6.75 \text {; } 95 \% \text { CI } 4.29-10.62 \text { ) than } \\
\text { among those without (POR } 2.27 \text {; } \\
\text { 95\%CI } 1.91-2.70 \text { ) }\end{array}$ \\
\hline
\end{tabular}


alcoholic beverages can cause an osmotic diarrhea $[6,30,31]$. Research has shown that IBD patients and alcoholic patients carry an intestinal bacterial dysbiosis [32-36]. A dysbiosis is believed to provide pathogens an opportunity to colonize and proliferate. Indeed, studies have shown IBD patients and alcoholics are at risk for increased infections [37].

Regarding alcohol, the prevalence of its consumption among IBD patients seems to be similar to that of the general population, whereas increased prevalence has been reported among children with IBD [18-20]. Even though light alcohol consumption has been reported by one study as a potential protective factor against the development of IBD, the majority of studies examining the impact of alcohol on IBD abdominal symptoms and disease activity reported deleterious effects [5,6,22-25,27]. Although studies failed to identify a single specific alcoholic beverage or quantity with the greatest impact on IBD symptoms $[6,23]$ some studies reported that other ingredients of alcoholic drinks rather than alcohol itself may play a role. Specifically, 2 studies concluded that high intake of sulfite, an additive commonly used in alcohol drinks, was associated with a higher risk of relapses and increased disease activity $[5,22]$, whereas one study reported that the consumption of alcoholic drinks that contain more sugars is associated with a greater prevalence of abdominal pain [24]. It should be noted, however, that the majority of studies made no objective measurements of the impact of alcohol on IBD symptoms; most of the symptoms were self-reported and therefore subjective.

Abdominal pain is a common and debilitating symptom among IBD patients [38]. In the past, narcotics were often contraindicated in patients with IBD for fear of precipitating toxic megacolon, but nowadays narcotics are commonly used in the IBD population [39]. Development of chronic abdominal pain is an under-recognized side effect of opioid use. Narcotic bowel syndrome, which occurs in a small proportion of chronic opioid users, consists of chronic or intermittent abdominal pain [40].

Narcotics use appears to be a significant factor that can complicate IBD, as a significant portion of IBD patients using narcotics meet the criteria for drug dependence, while it has also been reported that treatment with narcotics can significantly predict death among IBD patients $[13,14]$. It is estimated that approximately $5-13 \%$ of patients with IBD are on chronic narcotics in the outpatient setting [16]. Patients may also turn to narcotics, either as an alternative to normal therapy, because of concerns about the risks of medications, or as a supplement to standard treatment protocols [41]. Some studies suggest that patients with IBD who use marijuana can derive symptomatic benefits [42]. Cannabis use also provides symptom relief in patients with IBD, but is associated with a worse disease prognosis in patients with $\mathrm{CD}$, while exogenous cannabinoids can also reduce colitis [43]. Furthermore, through mechanisms such as stimulating antikinetic neurotransmitters, promoting dysmotility and injuring enteric neurons narcotics are associated with colonic pseudo-obstruction [44].

From the available studies it was evident that the use of narcotics for analgesia is prevalent among adult and young IBD patients and is associated with more active disease and impaired quality of life Furthermore, it is reported that psychological dysfunction is one of the factors contributing to pain perception by IBD patients [27]. Notably, all the included studies in the present review reported that, among IBD patients, those with a longer duration of disease and those with comorbid mental health illnesses were more likely to be narcotics users [14,15,28,29].

Interestingly, the majority of the studies examining alcohol consumption and also narcotic use among IBD patients adjusted their results according to the patients' age and sexwithout, however, taking ethnic or cultural differences into account. It is reported that the prevalence of alcohol and drugs use varies between different ethnic populations [45]. Therefore, future studies acknowledging this factor are needed.

In conclusion, overall, IBD is a multi-faceted chronic disease and as such it requires continuous vigilance and research into all its aspects. From the available literature data, it was evident that alcohol consumption among IBD patients may be associated with worsening of their symptoms, whereas a high proportion of IBD patients use narcotics to relieve their pain. Regarding alcohol, more studies are needed to establish its exact role in IBD, or perhaps to evaluate whether there is a potential specific quantity that IBD patients may safely consume. Concerning narcotics, the reasons for and the patterns of their increased use among IBD patients should be further assessed to address this very important issue.

\section{References}

1. Burisch J, Munkholm P. The epidemiology of inflammatory bowel disease. Scand J Gastroenterol 2015;50:942-951.

2. Andersen V, Olsen A, Carbonnel F, Tjønneland A, Vogel U. Diet and risk of inflammatory bowel disease. Dig Liver Dis 2012;44:185-194.

3. Sobczak M, Fabisiak A, Murawska N, et al. Current overview of extrinsic and intrinsic factors in etiology and progression of inflammatory bowel diseases. Pharmacol Rep 2014;66:766-775.

4. Legaki E, Gazouli M. Influence of environmental factors in the development of inflammatory bowel diseases. World J Gastrointest Pharmacol Ther 2016;7:112-125.

5. Magee EA, Edmond LM, Tasker SM, Kong SC, Curno R, Cummings $\mathrm{JH}$. Associations between diet and disease activity in ulcerative colitis patients using a novel method of data analysis. Nutr J 2005;4:7.

6. Swanson GR, Sedghi S, Farhadi A, Keshavarzian A. Pattern of alcohol consumption and its effect on gastrointestinal symptoms in inflammatory bowel disease. Alcohol 2010;44:223-228.

7. Sonnenberg GF, Artis D. Innate lymphoid cells in the initiation, regulation and resolution of inflammation. Nat Med 2015;21:698-708.

8. Jussila A, Virta LJ, Pukkala E, Färkkilä MA. Mortality and causes of death in patients with inflammatory bowel disease: a nationwide register study in Finland. J Crohns Colitis 2014;8:1088-1096.

9. Bergmann MM, Hernandez V, Bernigau W, et al. No association of alcohol use and the risk of ulcerative colitis or Crohn's disease: data from a European Prospective cohort study (EPIC). Eur J Clin Nutr 2017;71:566.

10. Carson HJ, Dudley MH, Knight LD, Lingamfelter D. Psychosocial complications of Crohn's disease and cause of death. J Forensic Sci 2014;59:568-570. 
11. Hanson KA, Loftus EV Jr, Harmsen WS, Diehl NN, Zinsmeister AR, Sandborn WJ. Clinical features and outcome of patients with inflammatory bowel disease who use narcotics: a case-control study. Inflamm Bowel Dis 2009;15:772-777.

12. Kerlin AM, Long M, Kappelman M, Martin C, Sandler RS. Profiles of patients who use marijuana for inflammatory bowel disease. Dig Dis Sci 2018;63:1600-1604.

13. Lichtenstein GR, Feagan BG, Cohen RD, et al. Serious infection and mortality in patients with Crohn's disease: more than 5 years of follow-up in the TREAT ${ }^{\text {mon }}$ registry. Am J Gastroenterol 2012;107:1409-1422.

14. Kaplan MA, Korelitz BI. Narcotic dependence in inflammatory bowel disease. J Clin Gastroenterol 1988;10:275-278.

15. Buckley JP, Cook SF, Allen JK, Kappelman MD. Prevalence of chronic narcotic use among children with inflammatory bowel disease. Clin Gastroenterol Hepatol 2015;13:310-315.

16. Cross RK, Wilson KT, Binion DG. Narcotic use in patients with Crohn's disease. Am J Gastroenterol 2005;100:2225-2229.

17. PRISMA. Transparent reporting of systematic reviews and metaanalyses. Available from: http://prisma-statement.org

18. Hendriksen C, Binder V. Social prognosis in patients with ulcerative colitis. Br Med J 30 1980;281:581-583.

19. Sørensen VZ, Olsen BG, Binder V. Life prospects and quality of life in patients with Crohn's disease. Gut 1987;28:382-385.

20. Weitzman ER, Ziemnik RE, Huang Q, Levy S. Alcohol and marijuana use and treatment nonadherence among medically vulnerable youth. Pediatrics 2015;136:450-457.

21. Jiang L, Xia B, Li J, et al. Risk factors for ulcerative colitis in a Chinese population: an age-matched and sex-matched casecontrol study. J Clin Gastroenterol 2007;41:280-284.

22. Jowett SL, Seal CJ, Pearce MS, et al. Influence of dietary factors on the clinical course of ulcerative colitis: a prospective cohort study. Gut 2004;53:1479-1484.

23. Zutshi M, Hull TL, Hammel J. Crohn's disease: a patient's perspective. Int J Colorectal Dis 2007;22:1437-1444.

24. Hey H, Schmedes A, Nielsen AA, Winding P, Grønbaek H. Effects of five different alcoholic drinks on patients with Crohn's disease. Scand J Gastroenterol 2007;42:968-972.

25. Triggs CM, Munday K, Hu R, et al. Dietary factors in chronic inflammation: food tolerances and intolerances of a New Zealand Caucasian Crohn's disease population. Mutat Res 2010;690:123-138.

26. Swanson GR, Tieu V, Shaikh M, Forsyth C, Keshavarzian A. Is moderate red wine consumption safe in inactive inflammatory bowel disease? Digestion 2011;84:238-244.

27. Cohen $A B$, Lee D, Long MD, et al. Dietary patterns and selfreported associations of diet with symptoms of inflammatory bowel disease. Dig Dis Sci 2013;58:1322-1328.

28. Edwards JT, Radford-Smith GL, Florin TH. Chronic narcotic use in inflammatory bowel disease patients: prevalence and clinical characteristics. J Gastroenterol Hepatol 2001;16:1235-1238.

29. Sanford D, Thornley P, Teriaky A, Chande N, Gregor J. Opioid use is associated with decreased quality of life in patients with Crohn's disease. Saudi J Gastroenterol 2014;20:182-187.
30. Kerr WC, Greenfield TK, Tujague J, Brown SE. The alcohol content of wine consumed in the US and per capita consumption: new estimates reveal different trends. Alcohol Clin Exp Res 2006;30:516-522.

31. Iglesias-Rey M, Barreiro-de Acosta M, Caamaño-Isorna F, et al. Psychological factors are associated with changes in the healthrelated quality of life in inflammatory bowel disease. Inflamm Bowel Dis 2014;20:92-102.

32. Taft TH, Keefer L. A systematic review of disease-related stigmatization in patients living with inflammatory bowel disease. Clin Exp Gastroenterol 2016;9:49-58.

33. Bernklev T, Jahnsen J, Henriksen M, et al. Relationship between sick leave, unemployment, disability, and health-related quality of life in patients with inflammatory bowel disease. Inflamm Bowel Dis 2006;12:402-412.

34. Petryszyn PW, Witczak I. Costs in inflammatory bowel diseases. Prz Gastroenterol 2016;11:6-13.

35. Hou JK, Lee D, Lewis J. Diet and inflammatory bowel disease: review of patient-targeted recommendations. Clin Gastroenterol Hepatol 2014;12:1592-1600.

36. Mutlu EA, Gillevet PM, Rangwala H, et al. Colonic microbiome is altered in alcoholism. Am J Physiol Gastrointest Liver Physiol 2012;302:G966-G978.

37. Bien J, Palagani V, Bozko P. The intestinal microbiota dysbiosis and Clostridium difficile infection: is there a relationship with inflammatory bowel disease? Therap Adv Gastroenterol 2013;6:53-68.

38. Srinath A, Young E, Szigethy E. Pain management in patients with inflammatory bowel disease: translational approaches from bench to bedside. Inflamm Bowel Dis 2014;20:2433-2449.

39. Long MD, Barnes EL, Herfarth HH, Drossman DA. Narcotic use for inflammatory bowel disease and risk factors during hospitalization. Inflamm Bowel Dis 2012;18:1869-1876.

40. Drossman D, Szigethy E. The narcotic bowel syndrome: a recent update. Am J Gastroenterol Suppl 2014;2:22-30.

41. Kerlin M, Long M, Kappelman M, Martin C, Sandler RS. Profiles of patients who use marijuana for inflammatory bowel disease. Dig Dis Sci 2018;63:1600-1604.

42. Storr M, Devlin S, Kaplan GG, Panaccione R, Andrews CN. Cannabis use provides symptom relief in patients with inflammatory bowel disease but is associated with worse disease prognosis in patients with Crohn's disease. Inflamm Bowel Dis 2014;20:472-480.

43. Sharkey KA, Wiley JW. The role of the endocannabinoid system in the brain-gut axis. Gastroenterology 2016;151:252-266.

44. Cappell MS. Colonic toxicity of administered drugs and chemicals. Am J Gastroenterol 2004;99:1175-1190.

45. Huang B, Grant BF, Dawson DA, et al. Race-ethnicity and the prevalence and co-occurrence of Diagnostic and Statistical Manual of Mental Disorders, Fourth Edition, alcohol and drug use disorders and Axis I and II disorders: United States, 2001 to 2002. Compr Psychiatry 2006;47:252-257. 